\title{
Acinetobacter species in intensive care unit-acquired infections in a tertiary care hospital
}

\section{Abstract}

Background: The aim of our study was to evaluate the antimicrobial resistance rates among pathogen microorganisms especially colistin resistant rates of Acinetobacter baumannii in intensive care unit (ICU)-acquired infections and to determine infection-specific correct treatment strategies.

Methods: The data of adult and newborn infant patients diagnosed with ICU-acquired infection in a tertiary education and research hospital in Bursa in 2014 and 2016 were analyzed, retrospectively.

Results: Acinetobacter baumannii was the most frequent pathogen of ICU-acquired infections in 2014 and 2016. There was a significant increase in colistin (CO) resistance rates in $A$. baumanii (0.0\%-6.8\%). A significant increase in $\mathrm{CO}$, cefepime (FEP), ciprofloxacin (CIP) resistance rates was established in all gram negative bacteria (0.0\%-7.9\%, $50.0 \%-91.9 \%, 54.7 \%-74.6 \%)$, respectively. A significant increase in the rate of detection of $A$. baumanii as the pathogen microorganism in respiratory tract infection (RTI) was established (53.9\% -79.5\%). In addition, the average ventilator-associated pneumonia (VIP) infection rate also increased in 2016 compared to 2014 (VIP rate 2014: 7.12, 2016: 7.45, per 1000 ventilator days). A significant decrease in the rate of detection of all gram negative microorganisms in the surgical site infection (SSI), and a significant increase in the rate of detection of all gram positive microorganisms in the SSI was determined.

Conclusion: Increased antimicrobial resistance, especially increased colistin resistance rates in ICU-acquired infections, necessitates the creation of new strategies in empirical therapy. Detection of antimicrobial resistance profiles of local and infectious pathogen microorganisms in ICUs is a good guide for correct antimicrobial management.
Sanem Karadag Gecgel ${ }^{1}$, Canan Demir ${ }^{2}$

1 Departments of Microbiology and Clinical Microbiology.

2 Infectious Diseases and Clinical Microbiology, University of Health Sciences, Yuksek Ihtisas Training and Research Hospital, Bursa, Turkey.

Contact information:

\section{Dr. Sanem Karadag Gecgel.}

Address: Department of Microbiology and Clinical Microbiology, Yuksek Ihtisas Training and Research Hospital, 152 Evler, Prof. Tezok Cd. No:2, Yıldırım/Bursa, Turkey.

Tel: 0-224-3605050.

”sanemkaradag@yahoo.com

Keywords

Colistin; Intensive Care Unit; Acinetonacter Baumannii; Antibiotic Resistance.

Recived 10-01-2018; Accepted 30-01-2018 


\section{Introduction}

The frequent use of broad spectrum antibiotics in intensive care unit (ICU), leads to increased rates of antimicrobial resistance and more frequent occurrence of multidrug-resistant microorganisms [13]. Increased antimicrobial resistance in ICU- acquired pathogens complicates treatment and limits new treatment options [4-6]. Nowadays colistin is frequently used as an effective antibiotic in ICUacquired infections caused by multiresistant gramnegative bacteria, but colistin resistance is also observed to be increasing in recent years [7-9]. In the management of antimicrobial resistance in ICUs; it is necessary to optimize specific diagnosis and treatment of infections. In addition, strategies for selection of antibiotics, optimization of dose and duration, prevention of the passage of resistant pathogenic microorganisms to the patient through correct infection control measures need to be developed [10]. Microbiologists, clinicians, and infection control staff must work together to identify specific common bacteria and antibiotic resistance profiles in ICUs to select the right antibiotics for treatment $[4,11]$.

The aim of this study was to evaluate the antimicrobial resistance rates especially colistin resistance rates of pathogen microorganisms in ICU-acquired infections and to determine infection-specific correct treatment strategies.

\section{Materials and methods}

\section{Data collection}

Bursa Yuksek Ihtisas Education and Research Hospital which is serviced 3 million population in Turkey, and is a tertiary care hospital with total of 147 ICUpatient beds including cardiovascular surgery (CVS), general surgery, internal medicine, cardiology, pediatry, newborn and reanimation departments. In our study, the data of adult and newborn infants diagnosed with ICU-acquired infection in 2014 and
2016 were analyzed retrospectively. ICU-acquired infections were determined according to the criteria of Centers for Disease Control and Prevention (CDC) guidelines for patients after length of ICU stay of 48 hours. ICU-acquired infections were categorized according to CDC criteria as blood stream infection $(B S I)$, respiratory tract infection (RTI), urinary tract infection (UTI), surgical site infection (SSI), skin and soft tissue infection (SSTI) and central nervous system infection (CNSI).

\section{Microbiological tests}

Bacterial and fungal cultivation were made from clinical samples (blood, cerebrospinal fluid, urine, wound, tissue, tracheal aspirate, etc.) of the ICU patients in microbiology laboratory. Positive blood and cerebrospinal fluid cultures were detected by automated blood culture system (BACTEC 9240 Blood Culture System; Becton Dickinson Biosciences). Identification and antibiograms of gram-positive and gram-negative bacteria and yeast fungi were determined from the pure isolates obtained from the cultures on the automated device (Vitek 2, bioMérieux, USA). All antibiotic resistance values were determined based on current EUCAST minimal inhibitor concentration (MIC) limit values. Amikacin (AN), ampicillin (AM), gentamicin (GN), imipenem (IMP), piperacillin-tazobactam (TPZ), FEP, cefotaxime (CTX), trimethoprim-sulfamethoxazole $(\mathrm{SXT})$, meropenem (MEM), ceftazidim (CAZ), ceftriaxone (CRO), tetracycline (TE), cefoxitin (FOX), teicoplanin (TEC), vancomycin (VA), linezolid (LNZ) and colistin (CO).

\section{Statistical analysis}

The data were analyzed using the Fisher-exact Chi square test and the Pearson Chi square test by the SPSS program version 21.0. Statistically significant difference was accepted as $p<0.05-95 \%$ and $p<0.01-99 \%$. 


\section{Results}

The distribution of all pathogen microorganisms according to period of detection was shown in ICU-acquired infections (Table 1). Acinetobacter baumannii was the most frequent pathogen detected in ICU- acquired infections in 2014 and 2016, among gram-negative bacteria, whereas among gram-positive bacteria coagulase-negative Stapylococcus (CNS), and Candida albicans among Candida spp. was the most frequent isolates.

Antibiotic resistance rates of gram-negative pathogens in ICU-acquired infections were compared between 2014 and 2016 (Table 2, 3).

There was a significant increase in $\mathrm{CO}$ resistance rates in $A$. baumanii $(0.0 \%-6.8 \%, p<0.05)$. There was a significant increase in $\mathrm{GN}$ resistance rates in Klebsiella pneumoniae (41.9\% -80.3\%, p <0.01). A significant decrease in TPZ resistance rates was found in Pseudomonas aeruginosa (65.1\% - 31.4\%, $\mathrm{p}<0.01)$.

A significant increase in $\mathrm{CO}$ and FEP resistance rates was established in all gram negative bacteria (0.0\%-7.9\%, 50.0\% -91.9\%, p<0.01). CIP resistance rates were also significantly increased $(54.7 \%$ $-74.6 \%, p<0.05)$. The increase of $A M, G N, C A Z$, TPZ, IMP, MEM, and SXT resistance ratios were not statistically significant. The decrease in CTX and $\mathrm{CRO}$ resistance ratios was not statistically significant. AN resistance rate did not change.

Antibiotic resistance rates of gram-positive pathogens in ICU-acquired infections were compared between 2014 and 2016 (Table 4).

There was a significant decrease in $\mathrm{GN}$ resistance of CNS (76.0\%-42.1\%, p<0.05) and a significant decrease in FOX resistance in Stapylococcus aureus (100.0\% -75.0\%, p<0.05).

A significant decrease in FOX and GN resistance was determined in all gram positive bacteria (100.0\% -75.0\%, 76.0\% -42.1\%, p<0.05). The decrease of LNZ, SXT, VA and TE resistance ratios was not statistically significant, and the increase of AM resistance was not statistically significant.
Table 1. Distribution of all recovered pathogens from ICU-acquired infections over the 2-year (2014 \& 2016).

\begin{tabular}{|c|c|c|c|c|}
\hline \multirow{2}{*}{ Microorganism } & \multicolumn{2}{|c|}{2014} & \multicolumn{2}{|c|}{2016} \\
\hline & $\mathrm{n}$ & $\%$ & $n$ & $\%$ \\
\hline \multicolumn{5}{|l|}{ Gram Negative Bacteria } \\
\hline Acinetobacter baumannii & 89 & 26.0 & 73 & 25.4 \\
\hline Acinetobacter spp. & 53 & 15.5 & 6 & 2.1 \\
\hline Pseudomonas aeruginosa & 43 & 12.5 & 35 & 12.2 \\
\hline Klebsiella pneumoniae & 31 & 9.0 & 69 & 24 \\
\hline Escherichia coli & 13 & 3.8 & 23 & 8.0 \\
\hline Enterobacter aerogenes & 6 & 1.8 & 1 & 0.3 \\
\hline Pseudomonas spp. & 5 & 1.5 & 3 & 1.0 \\
\hline Klebsiella spp. & 5 & 1.5 & 0 & 66.47 \\
\hline Enterobacter spp. & 3 & 0.9 & 3 & 1.0 \\
\hline Serratia marcescens & 3 & 0.9 & 2 & 0.7 \\
\hline Enterobacter cloacae & 2 & 0.6 & 3 & 1.0 \\
\hline Proteus mirabilis & 1 & 0.3 & 4 & 1.4 \\
\hline Stenotrophomonas maltophilia & 1 & 0.3 & 1 & 0.3 \\
\hline Citrobacter spp. & 0 & & 2 & 0.7 \\
\hline Burkholderia cepacia & 0 & & 1 & 0.3 \\
\hline Morganella morganii & 0 & & 1 & 0.3 \\
\hline Salmonella spp. & 0 & & 1 & 0.3 \\
\hline Klebsiella oxytoca & 0 & & 0 & \\
\hline Other & 0 & & 0 & \\
\hline \multicolumn{5}{|l|}{ Gram Negative Bacterias } \\
\hline Fermantatives & 65 & 19 & 111 & 38.5 \\
\hline Non-Fermantatives & 190 & 55.5 & 117 & 40.6 \\
\hline Total & 255 & 74.6 & 228 & 79.2 \\
\hline \multicolumn{5}{|l|}{ Gram Positive Bacteria } \\
\hline CNS & 25 & 7.3 & 19 & 6.6 \\
\hline Staphylococcus aureus & 19 & 5.5 & 12 & 4.3 \\
\hline Enterococcus faecalis & 8 & 2.3 & 7 & 2.5 \\
\hline Enterococcus faecium & 2 & 0.6 & 6 & 2.1 \\
\hline Enterococcus spp. & 6 & 1.8 & 2 & 0.7 \\
\hline Streptococcus pneumoniae & 1 & 0.3 & 0 & \\
\hline Gram Positive Bacterias & 61 & 17.8 & 46 & 15.9 \\
\hline \multicolumn{5}{|l|}{ All Candida spesies } \\
\hline Candida spp. & 13 & 3.8 & 7 & 2.5 \\
\hline Candida albicans & 9 & 2.6 & 3 & 1.0 \\
\hline Candida glabrata & 0 & & 1 & 0.3 \\
\hline Candida parapsilosis & 3 & 0.9 & 2 & 0.7 \\
\hline Candida tropicalis & 1 & 0.3 & 1 & 0.3 \\
\hline All Candida spesies & 26 & 7.6 & 14 & 4.9 \\
\hline Total & 342 & 100 & 288 & 100 \\
\hline
\end{tabular}


Table 2. Comparison of antimicrobial resistance rates of gram negative pathogens in ICU-acquired infections over the 2-year (2014 \& 2016).

\begin{tabular}{|c|c|c|c|c|c|c|c|c|c|c|c|c|c|c|c|}
\hline \multirow[t]{2}{*}{ Pathogens } & \multirow{2}{*}{ Period } & \multicolumn{2}{|c|}{ Amikacin } & \multicolumn{2}{|c|}{ Ampicillin } & \multicolumn{2}{|c|}{ Gentamicin } & \multicolumn{2}{|c|}{ Imipenem } & \multicolumn{2}{|c|}{$\begin{array}{l}\text { Piperacillin } \\
\text { /Tazobactam }\end{array}$} & \multicolumn{2}{|c|}{ Cefepime } & \multicolumn{2}{|c|}{ Cefotaxime } \\
\hline & & $\%$ & $p$ & $\%$ & $p$ & $\%$ & $p$ & $\%$ & $p$ & $\%$ & $p$ & $\%$ & $p$ & $\%$ & $p$ \\
\hline \multirow{2}{*}{ E.coli } & 2014 & 30.8 & \multirow{2}{*}{, 727} & & & 38.5 & \multirow{2}{*}{1,00} & & & 61.5 & \multirow{2}{*}{1,00} & & & & \\
\hline & 2016 & 39.1 & & & & 43.5 & & & & 65.2 & & & & & \\
\hline \multirow{2}{*}{$\begin{array}{l}\text { Klebsiella } \\
\text { pneumoniae }\end{array}$} & 2014 & 35.5 & \multirow{2}{*}{,384 } & & & 41.9 & \multirow{2}{*}{, $000 * *$} & & & 58.1 & \multirow{2}{*}{, 160 } & & & & \\
\hline & 2016 & 46.4 & & & & 80.3 & & & & 73.9 & & & & & \\
\hline \multirow{2}{*}{$\begin{array}{l}\text { Pseudomonas } \\
\text { aeruginosa }\end{array}$} & 2014 & 44.2 & \multirow{2}{*}{,350 } & & & & & 48.8 & 652 & 65.1 & \multirow{2}{*}{$006 * *$} & & & & \\
\hline & 2016 & 31.4 & & & & & & 42.9 & 652 & 31.4 & & & & & \\
\hline \multirow{2}{*}{$\begin{array}{l}\text { Acinetobacter } \\
\text { baumanii }\end{array}$} & 2014 & 62.9 & \multirow{2}{*}{1,00} & & & 69.7 & \multirow{2}{*}{,602 } & & & & & & & & \\
\hline & 2016 & 63.0 & & & & 74.0 & & & & & & & & & \\
\hline \multirow{2}{*}{$\begin{array}{l}\text { Acinetobacter } \\
\text { spp. }\end{array}$} & 2014 & & & & & 77.4 & \multirow{2}{*}{, 440} & & & & & & & & \\
\hline & 2016 & & & & & 66.7 & & & & & & & & & \\
\hline \multirow{2}{*}{$\begin{array}{l}\text { Pseudomonas } \\
\text { spp. }\end{array}$} & 2014 & 40.0 & \multirow{2}{*}{1,00} & & & & & & & 40.0 & \multirow{2}{*}{1,00} & & & & \\
\hline & 2016 & 33.3 & & & & & & & & 66.7 & & & & & \\
\hline \multirow{2}{*}{$\begin{array}{l}\text { All Gram } \\
\text { Negative } \\
\text { Bacterias }\end{array}$} & 2014 & 48.2 & \multirow{2}{*}{1,00} & 94.1 & 100 a & 62.3 & \multirow{2}{*}{, 842} & 36.4 & 305 & 56.4 & \multirow{2}{*}{,604 } & 50.0 & \multirow{2}{*}{, $000^{* *}$} & 72.7 & 10 \\
\hline & 2016 & 48.2 & & 100,0 & $1,00^{a}$ & 63.3 & & 44.4 & ,395 & 60.1 & & 91.9 & & 70.0 & 1,00 \\
\hline
\end{tabular}

Table 3. Comparison of antibiotic resistance rates of gram-negative pathogens in ICU-acquired infections over the 2-year (2014 \& 2016).

\begin{tabular}{|c|c|c|c|c|c|c|c|c|c|c|c|c|c|}
\hline \multirow[t]{2}{*}{ Pathogens } & \multirow[t]{2}{*}{ Period } & \multicolumn{2}{|c|}{$\begin{array}{c}\text { Trimethoprim- } \\
\text { sulfamethoxazole }\end{array}$} & \multicolumn{2}{|c|}{ Meropenem } & \multicolumn{2}{|c|}{ Ciprofloxacin } & \multicolumn{2}{|c|}{ Ceftazidime } & \multicolumn{2}{|c|}{ Ceftriaxone } & \multicolumn{2}{|c|}{ Colistin } \\
\hline & & $\%$ & $p$ & $\%$ & $p$ & $\%$ & $p$ & $\%$ & $p$ & $\%$ & p & $\%$ & $p$ \\
\hline \multirow{2}{*}{ E.coli } & 2014 & 69.2 & \multirow{2}{*}{$484^{a}$} & & & & & 69.2 & \multirow{2}{*}{$1,00 a$} & 61.5 & \multirow{2}{*}{1,00} & & \\
\hline & 2016 & 52.2 & & & & & & 65.2 & & 65.2 & & & \\
\hline \multirow{2}{*}{$\begin{array}{l}\text { Klebsiella } \\
\text { pneumoniae }\end{array}$} & 2014 & 58.1 & \multirow{2}{*}{$1,00 a$} & & & & & 87.1 & \multirow{2}{*}{$1,00 a$} & 58.1 & \multirow{2}{*}{, 160 } & & \\
\hline & 2016 & 58.0 & & & & & & 87.0 & & 73.9 & & & \\
\hline \multirow{2}{*}{$\begin{array}{l}\text { Pseudomonas } \\
\text { aeruginosa }\end{array}$} & 2014 & & & & & 51.2 & \multirow{2}{*}{, $108^{a}$} & 62.8 & \multirow{2}{*}{, $254^{a}$} & 65.1 & \multirow{2}{*}{, $006 * *$} & & \multirow{4}{*}{, $017 a^{*}$} \\
\hline & 2016 & & & & & 31.4 & & 48.6 & & 31.4 & & & \\
\hline \multirow{2}{*}{$\begin{array}{l}\text { Acinetobacter } \\
\text { baumanii }\end{array}$} & 2014 & & & & & & & & & & & 0.0 & \\
\hline & 2016 & & & & & & & & & & & 6.8 & \\
\hline \multirow{2}{*}{$\begin{array}{l}\text { Acinetobacter } \\
\text { spp. }\end{array}$} & 2014 & & & & & & & & & & & & \\
\hline & 2016 & & & & & & & & & & & & \\
\hline \multirow{2}{*}{$\begin{array}{l}\text { Pseudomonas } \\
\text { spp. }\end{array}$} & 2014 & & & & & 40.0 & 1967 & & & 40.0 & 100 & & \\
\hline & 2016 & & & & & 100.0 & ,196a & & & 66.7 & 1,00 & & \\
\hline \multirow{2}{*}{$\begin{array}{l}\text { All Gram } \\
\text { Negative } \\
\text { Bacterias }\end{array}$} & 2014 & 56.9 & \multirow{2}{*}{, $457^{a}$} & 9.1 & \multirow{2}{*}{$1,00^{\mathrm{a}}$} & 54.7 & $012 a *$ & 72.8 & \multirow{2}{*}{$1,00^{\mathrm{a}}$} & 56.4 & \multirow{2}{*}{, 604} & 0.0 & \multirow{2}{*}{, $001 a^{* *}$} \\
\hline & 2016 & 62.9 & & 17.9 & & 74.6 & , & 73.3 & & 60.1 & & 7.9 & \\
\hline
\end{tabular}


Table 4. Comparison of antimicrobial resistance of gram-positive pathogens in ICU-acquired infections over the 2-year (2014 \& 2016).

\begin{tabular}{|c|c|c|c|c|c|c|c|c|c|c|c|c|c|c|c|}
\hline \multirow{2}{*}{ Pathogens } & \multirow{2}{*}{ Period } & \multicolumn{2}{|c|}{ Amikacin } & \multicolumn{2}{|c|}{ Linezolid } & \multicolumn{2}{|c|}{ Tetracycline } & \multicolumn{2}{|c|}{$\begin{array}{c}\text { Trimethoprim / } \\
\text { sulfamethoxazole }\end{array}$} & \multicolumn{2}{|c|}{ Vancomycin } & \multicolumn{2}{|c|}{ Gentamicin } & \multicolumn{2}{|c|}{ Cefoxitin } \\
\hline & & $\%$ & $p$ & $\%$ & $p$ & $\%$ & $p$ & $\%$ & $p$ & $\%$ & $p$ & $\%$ & $p$ & $\%$ & $p$ \\
\hline \multirow{2}{*}{$\begin{array}{l}\text { Stapylococcus } \\
\text { aureus }\end{array}$} & 2014 & & & & & & & 61.5 & 717 & & & & & \multirow{2}{*}{\multicolumn{2}{|c|}{$\begin{array}{c}100.0 \\
75.0\end{array}, 049 *$}} \\
\hline & 2016 & & & & & & & 65.2 & , & & & & & & \\
\hline \multirow{2}{*}{$\begin{array}{l}\text { Enterococcus } \\
\text { faecalis }\end{array}$} & 2014 & 25.0 & \multirow{2}{*}{, 608} & & & & & 58.1 & & 50.0 & \multirow{2}{*}{, 077} & & & & \\
\hline & 2016 & 42.9 & & & & & & 73.9 & & 0.0 & & & & & \\
\hline \multirow{2}{*}{ CNS } & 2014 & & & & & 36.0 & \multirow{2}{*}{$1,00^{a}$} & 65.1 & 067 & 4.0 & \multirow{2}{*}{1,00} & 76.0 & \multirow{2}{*}{, $031 *$} & & \\
\hline & 2016 & & & & & 36.8 & & 31.4 & , & 0.0 & & 42.1 & & & \\
\hline \multirow{2}{*}{$\begin{array}{l}\text { Enterococcus } \\
\text { faecium }\end{array}$} & 2014 & & & & & & & & & 0.0 & \multirow{2}{*}{,464 } & & & & \\
\hline & 2016 & & & & & & & & & 50.0 & & & & & \\
\hline \multirow{2}{*}{$\begin{array}{l}\text { All Gram } \\
\text { Positive } \\
\text { Bacterias }\end{array}$} & 2014 & 35.7 & \multirow{2}{*}{, 128 } & 2.4 & \multirow{2}{*}{1,00} & 43.4 & \multirow{2}{*}{, $787^{a}$} & & \multirow{2}{*}{, 064} & 10.0 & \multirow{2}{*}{1,00} & 76.0 & \multirow{2}{*}{, $031 *$} & 100.0 & \multirow{2}{*}{, $049^{*}$} \\
\hline & 2016 & 69.2 & & 0.0 & & 36.8 & & & & & & 42.1 & & 75.0 & \\
\hline
\end{tabular}

The rates of ICU-acquired infections were compared in gram-negative pathogens between 2014 and 2016 (Table 5).

There was a significant decrease in the rate of detection of $A$. baumanii as the pathogen microorganism in $\mathrm{BSI}(40.4 \%-15.1 \%, \mathrm{p}<0.01)$ and a significant increase in the rate of detection as the pathogen microorganism in RTI (53.9\% $-79.5 \%, \mathrm{p}<0.01)$. A significant decrease in the rate of detection of $K$. pneumoniae as the pathogen microorganism in UTI was detected $(25.8 \%-8.7 \%$, p < 0.05$)$.

The rate of detection of all gram-negative bacteria as pathogen microorganism in SSI were significantly decreased $(3.1 \%-0.0 \%, p<0.01)$. The decrease of in the rate of detection as the pathogen microorganism in BSI and UTI and the increase in the rate of detection as an pathogen microorganism in RTI, SSTI and CNSI was not statistically significant.

Table 5. Comparison of ICU-acquired infection rates for gram negative pathogens during the 2-year (2014 \& 2016).

\begin{tabular}{|c|c|c|c|c|c|c|c|c|c|c|c|c|c|}
\hline \multirow{2}{*}{ Pathogens } & \multirow{2}{*}{ Period } & \multicolumn{2}{|c|}{ BSI } & \multicolumn{2}{|c|}{ RTI } & \multicolumn{2}{|c|}{ UTI } & \multicolumn{2}{|c|}{ SSI } & \multicolumn{2}{|c|}{ SSTI } & \multicolumn{2}{|c|}{ CNSI } \\
\hline & & $\%$ & $\mathrm{p}$ & $\%$ & $\mathrm{p}$ & $\%$ & $\mathrm{p}$ & $\%$ & $p$ & $\%$ & $p$ & $\%$ & $p$ \\
\hline \multirow{2}{*}{ E.coli } & 2014 & 38.5 & \multirow{2}{*}{,475 } & 7.7 & \multirow{2}{*}{, 634} & 53.8 & \multirow{2}{*}{,310 } & 0.0 & & 0.0 & \multirow{2}{*}{,274 } & 0.0 & \multirow{2}{*}{, 508} \\
\hline & 2016 & 26.1 & & 17.4 & & 34.8 & & 0.0 & & 17.4 & & 8.3 & \\
\hline \multirow{2}{*}{ Klebsiella pneumoniae } & 2014 & 29.0 & \multirow{2}{*}{, 191 } & 41.9 & \multirow{2}{*}{1,00} & 25.8 & \multirow{2}{*}{, 031 * } & 3.2 & \multirow{2}{*}{,310 } & 0.0 & \multirow{2}{*}{,568 } & 0.0 & \multirow{2}{*}{, 568} \\
\hline & 2016 & 43.5 & & 42.0 & & 8.7 & & 0.0 & & 2.9 & & 2.9 & \\
\hline \multirow{2}{*}{$\begin{array}{l}\text { Pseudomonas } \\
\text { aeruginosa }\end{array}$} & 2014 & 16.3 & \multirow{2}{*}{, 538} & 60.5 & \multirow{2}{*}{,230 } & 14.0 & \multirow{2}{*}{,119 } & & & 7.0 & \multirow{2}{*}{,696 } & 2.3 & \multirow{2}{*}{1,00} \\
\hline & 2016 & 11.1 & & 75.0 & & 2.8 & & & & 11.1 & & 0.0 & \\
\hline \multirow{2}{*}{$\begin{array}{l}\text { Acinetobacter } \\
\text { baumanii }\end{array}$} & 2014 & 40.4 & \multirow{2}{*}{, $000 * *$} & 53.9 & \multirow{2}{*}{$001 * *$} & 2.2 & \multirow{2}{*}{1,00} & 2.2 & \multirow{2}{*}{, 502} & 1.1 & \multirow{2}{*}{1,00} & 0.0 & \multirow{2}{*}{,202 } \\
\hline & 2016 & 15.1 & & 79.5 & & 2.7 & & 0.0 & & 0.0 & & 2.7 & \\
\hline \multirow{2}{*}{$\begin{array}{l}\text { All Gram Negative } \\
\text { Bacterias }\end{array}$} & 2014 & 32.9 & \multirow{2}{*}{, 432} & 50.6 & & 10.2 & & 3.1 & & 3.1 & & 0.4 & \\
\hline & 2016 & 29.4 & & 56.6 &, 201 & 8.8 & ,643 & 0.0 & * & 5.3 &, 261 & 2.6 & ל5, \\
\hline
\end{tabular}


Table 6. Comparison of ICU-acquired infection rates in gram-positive and Candida microorganisms during the 2-year (2014 \& 2016).

\begin{tabular}{|c|c|c|c|c|c|c|c|c|c|}
\hline \multirow{2}{*}{ Microorganisms } & \multirow{2}{*}{ Period } & \multicolumn{2}{|c|}{ BSI } & \multicolumn{2}{|c|}{ RTI } & \multicolumn{2}{|c|}{ UTI } & \multicolumn{2}{|c|}{ SSI } \\
\hline & & $\%$ & $p$ & $\%$ & $p$ & $\%$ & p & $\%$ & $p$ \\
\hline \multirow{2}{*}{ Stapylococcus aureus } & 2014 & 78.9 & \multirow{2}{*}{,253 } & 21.1 & \multirow{2}{*}{,676 } & & & 0.0 & \multirow{2}{*}{,387 } \\
\hline & 2016 & 58.3 & & 33.3 & & & & 8.3 & \\
\hline \multirow{2}{*}{ Enterococcus faecalis } & 2014 & 50.0 & \multirow{2}{*}{1,00} & & & 50.0 & \multirow{2}{*}{1,00} & & \\
\hline & 2016 & 57.1 & & & & 42.9 & & & \\
\hline \multirow{2}{*}{ CNS } & 2014 & 100.0 & \multirow{2}{*}{,444a } & & & 0.0 & \multirow{2}{*}{1,00} & 0.0 & \multirow{2}{*}{, 444} \\
\hline & 2016 & 95.0 & & & & 0.0 & & 5.0 & \\
\hline \multirow{2}{*}{ Enterococcus faecium } & 2014 & 100.0 & \multirow{2}{*}{ 1,00a } & & & 0.0 & \multirow{2}{*}{1,00} & & \\
\hline & 2016 & 83.3 & & & & 16.7 & & & \\
\hline \multirow{2}{*}{ All Gram Positive Bacterias } & 2014 & 80.3 & \multirow{2}{*}{, 487} & 8.2 & \multirow{2}{*}{1,00} & 11.5 & \multirow{2}{*}{,754 } & 0.0 & \multirow{2}{*}{, $032^{\star}$} \\
\hline & 2016 & 73.9 & & 8.7 & & 8.7 & & 8.7 & \\
\hline \multirow{2}{*}{ Candida spp. } & 2014 & 50.0 & \multirow{2}{*}{1,00} & & & 50.0 & \multirow{2}{*}{1,00} & & \\
\hline & 2016 & 57.1 & & & & 42.9 & & & \\
\hline \multirow{2}{*}{ Candida albicans } & 2014 & 66.7 & \multirow{2}{*}{, 509} & & & 33.3 & \multirow{2}{*}{, 509} & & \\
\hline & 2016 & 100.0 & & & & 0.0 & & & \\
\hline \multirow{3}{*}{ All Candida spesies } & 2014 & 60.0 & \multirow{2}{*}{, 514} & & & 40.0 & \multirow{2}{*}{, 514} & & \\
\hline & 2016 & 71.4 & & & & 28.6 & & & \\
\hline & & & & & & & & & $p<0.05$ \\
\hline
\end{tabular}

The distribution of ICU-acquired infection rates in gram-positive and fungal pathogens were shown between the years 2014 and 2016 (Table 6).

A significant increase in the rate of detection of all gram positive bacteria as the pathogen microorganism in SSI was found $(0.0 \%-8.7 \%$, $p<0.05)$. The increase of in the rate of detection as a pathogen microorganism in RTI and the decrease of in the rate of detection as a pathogen microorganism in BSI and UTI was not statistically significant.

A non-significant increase in BSI and a non-significant decrease in UTI were detected in the rates of all Candida species and Candida albicans.

\section{Discussion}

Routine surveillance and reporting on prevalence of infection and antimicrobial resistance patterns of isolates among patients in ICUs are essential measurements to control misuse of certain antimicrobial drugs and to reduce emergence of more resistant pathogens. Colistin resistance rates ranging from $0.9 \%$ to $40.7 \%$ have been reported between 2001 and 2011, in many countries of Asia, Europe and the United States [12, 13]. According to this study, there was a significant increase in colistin resistance rates among $A$. baumanii and all gram-negative bacteria isolates $(p<0.05$, $\mathrm{p}<0.01$ ) (Table 3). First, the rates of colistin resistance reported in A. baumanii were 5.9\% in 1999 in the Czech Republic. According to studies from Turkey, colistin resistance rates were reported to be ranged between $0 \%$ in 2014 and $0.6 \%$ in 2016 $[14,15]$. The primary cause of increased colistin resistance rates in our study was the significant especially for CIP, FEP, IMP, MEM, and TPZ which were frequently used in treatment of ICU-acquired infections caused by gram-negative pathogens (Table 2, 3). 
In our hospital, many antibiotics including carbapenems are becoming useless in the treatment of multidrug resistant ICU-acquired $A$. baumannii infections. For this reason, colistin has been started to be used in empirical treatment. However, a recently increase in colistin resistance to already exist multi-resistant gram-negative causing infections further complicates the selection of already limited treatment options. Studies from different countries have shown that increasing CIP, TPZ, and carbapenem resistant in gram-negative bacteria isolates from intensive care units, as well as the increasing of community antimicrobial resistance rates, have affected empirical treatment choice [16, 17]. Common alternative antimicrobial treatment strategies need to be developed where the use of colistin should be limited for empirical treatment of patients of intensive care units as has been done in our hospital.

The increase in the detection rate of $A$. baumanii as a pathogen causing RTIs was found significant compared to other gram-negative pathogens $(p<0.01)$ (Table 5). The average ventilator-associated pneumonia (VIP) infection rate also increased in 2016 compared to 2014 (VIP rate 2014: 7.12, 2016: 7.45 per 1000 ventilator days). The efficacy of colistin treatment was noticed clearly in multidrug resistant $A$. baumanii pneumonias, especially among patients in ICU-acquired infections. Several studies have recommednded a combined treatment with colistin [18, 19]. In our hospital, the detection of multi-resistant $A$. baumanii in ICU-acquired infections resulted in increasing the use of colistin and conseguently a significant increase in colistin resistance was detected. Increasing infection control measures by improving isolation conditions, especially in our patients with RTIs, which were frequently infected with multi-drug resistant $A$. baumanii, may lead to a decrease in colistin resistance rates as has been demonstrated by other studies $[20,21]$. In addition, we found a significant decrease in the rate of detection of all gram negative and gram positive bacteria as pathogens in BSI and UTI (Table 5, 6). When invasive device associated infections in ICU were examined, central venous catheter-related bloodstream infection rate $(2.98 \% / 2014$ versus 2.97\%/2016:) and catheter-related urinary tract infection rate $(0.97 \% / 2014$ versus $0.61 \% / 2016)$ were also found to be slighlty decreased in our hospital. Several studies havefound that The incidence of ICU-acquired infections, the distribution of pathogens and antibiotic resistance, and the frequency of infection from invasive devices are interrelated and should be analysed togather [22, 23]. Therefore, a decrease in using invasive devices can reduce the frequency of acquired multidrug resistant bacteria [23].

This study demonstraded that gram-negative pathogens were more common in ICU-acquired infections in 2016 than 2014 (Table 1). In addition, a significant decrease in the rate of detection of all gram-negative bacteria isolates in the SSI $(p<0.01)$, and also a significant increase in the rates of all gram positive bacteria in the SSI $(p<0.05)$ was observed (Table 5). The reason for the increase of SSI caused by gram-positive pathogens is related to patients who were admitted to the CVS and gynecology ICUs. Therefore, it is also important to choose empiric antibiotherapy which are effective against gram-positive.

\section{Conclusion}

In conclusion, increased antimicrobial resistance, especially increased colistin resistance rates in ICUinfected patients, necessitates the creation of new strategies in empirical therapy. Reporting of antimicrobial resistance profiles of recovered pathogens in ICUs is recommended guide for correct antimicrobial management and control nosocomial infection. 


\section{Acknowledgements}

We thank the dedicated staff members at Clinical Microbiology, Bursa Yuksek Ihtisas Training and Research Hospital for their technical support.

\section{Funding}

There is no relevant sources of funding for this study.

\section{Conflicts of interest}

There are no conflicts of interest for this study.

\section{References}

1. Mitharwal SM, Yaddanapudi S, Bhardwaj N, Gautam V, Biswal $M$, et al. Intensive care unit-acquired infections in a tertiary care hospital: An epidemiologic survey and influence on patient outcomes. Am J Infect Control 2016; 44: 113-7.

2. Ariffin N, Hasan H, Ramli N, Ibrahim NR, Taib F, et al. Comparison of antimicrobial resistance in neonatal and adult intensive care units in a tertiary teaching hospital. Am J Infect Control 2012; 40: $572-5$.

3. Axente C, Licker M, Moldovan R, Hogea E, Muntean D, Horhat F, Bedreag O, Sandesc D, Papurica M, Dugaesescu D, Voicu M, Baditoiu L. Antimicrobial consumption, costs and resistance patterns: a two year prospective study in a Romanian intensive care unit. BMC Infect Dis. 2017; 17: 358. doi: 10.1186/s12879017-2440-7.

4. Fraimow HS, Tsigrelis $C$. Antimicrobial resistance in the intensive care unit: mechanisms, epidemiology, and management of specific resistant pathogens. Crit Care Clin 2011; 27: 163-205.

5. Ritchie DJ, Alexander BT, Finnegan PM. New antimicrobial agents for use in the intensive care unit. Infect Dis Clin North Am 2009; 23: 665-81.

6. Cassir N, Rolain JM, Brouqui P. A new strategy to fight antimicrobial resistance: the revival of old antibiotics. Front Microbiol 2014; 5: 551.

7. Yilmaz GR, Dizbay M, Guven T, Pullukcu H, Tasbakan M, et al. Risk factors for infection with colistin-resistant gram-negative microorganisms: a multicenter study. Ann Saudi Med 2016; 36: 216-22.

8. Lee JY, Choi MJ, Choi HJ, Ko KS. Preservation of acquired colistin resistance in gram-negative bacteria. Antimicrob Agents Chemother2015; 60: 609-12.
9. Halaby T, Al Naiemi N, Kluytmans J, van der Palen J, Vandenbroucke-Grauls CM. Emergence of colistin resistance in Enterobacteriaceae after the introduction of selective digestive tract decontamination in an intensive care unit. Antimicrob Agents Chemother 2013; 57: 3224-9.

10. Centers for Disease Control and Prevention. Campaign to prevent antimicrobial resistance in healthcare settings. MMWR Morb Mortal Wlkly Rep. 2002; 51: 343.

11. Beardsley J, Williamson J, Johnson J, et al. Using local microbiologic data to develop institution-specific guidelines for the treatment of hospital acquired pneumonia. Chest 2006;130:787-93.

12. Arroyo LA, Garcia-Curiel A, Pachon- Ibanez ME, van den Barselaar M, Nordmann $P$, et al. Reliability of the E-test method for detection of colistin resistance in clinical isolates of Acinetobacter baumannii. J Clin Microbiol 2005; 43: 903-5.

13. Cai $Y$, Chai $D$, Wang $R$, Liang B, Bai N. Colistin resistance of Acinetobacter baumannii: clinical reports, mechanisms and antimicrobial strategies. J Antimicrob Chemother 2012; 67: 1607-15.

14. Beriş FŞ, BudakEE, Gülek D, Uzun A, ÇizmeciZ, et aal. Investigation of the frequency and distribution of beta-lactamase genes in the clinical isolates of Acinetobacter baumannii collected from different regions of Turkey: a multicenter study. Mikrobiyol Bul 2016; 50: 511-21.

15. Karagöz A, Baran I, Aksu N, Acar S, Durmaz R. Characterization and determination of antibiotic resistance profiles of a single clone Acinetobacter baumannii strains isolated from blood cultures. Mikrobiyol Bul 2014; 48: 566-76.

16. Sligl WI, Dragan T, Smith SW. Nosocomial Gram-negative bacteremia in intensive care: epidemiology, antimicrobial susceptibilities, and outcomes. Int J Infect Dis 2015; 37: 129-34.

17. Clark NM, Patterson J, Lynch JP. Antimicrobial resistance among gram-negative organisms in the intensive care unit. Curr Opin Crit Care 2003; 9: 413-23.

18. Shojaei L, Mohammadi M, Beigmohammadi MT, Doomanlou M, Abdollahi A, et al. Clinical response and outcome of pneumonia due to multi-drug resistant Acinetobacter baumannii in critically ill patients. Iran J Microbiol. 2016; 8: 288-29.

19. Gu WJ, Wang F, Tang L, Bakker J, Liu JC. Colistin for the treatment of ventilator-associated pneumonia caused by multidrug-resistant Gram-negative bacteria: a systematic review and meta-analysis. Int J Antimicrob Agents 2014; 44: 477-85.

20. Tekin R, Dal T, Pirinccioglu H, Oygucu SE. A 4-year surveillance of device-associated nosocomial infections in a neonatal intensive care unit. Pediatr Neonatol 2013; 54: 303-8. 
21. El-Saed A, Balkhy HH, Al-Dorzi HM, Khan R, Rishu AH, Arabi YM. Acinetobacter is the most common pathogen associated with late-onset and recurrent ventilator-associated pneumonia in an adult intensive care unit in Saudi Arabia. Int J Infect Dis 2013; 17: 696-701.

22. Leblebicioglu H, Erben N, Rosenthal VD, Atasay B, Erbay A, et al. International Nosocomial Infection Control Consortium (INICC) national report on device-associated infection rates in 19 cities of Turkey, data summary for 2003-2012. Ann Clin Microbiol Antimicrob 2014: 18; 13:51.

23. Rosenthal VD, Maki DG, Graves N. The International Nosocomial Infection Control Consortium (INICC): goals and objectives, description of surveillance methods, and operational activities. Am J Infect Control 2008; 36: 1-12.

Publish in The International Arabic Journal of Antimicrobial Agents

The Journal is an open access peer-reviewed journal that publishes scientific papers about all aspects of antimicrobials. The journal will publish original research articles, reviews, brief reports and case reports dealing with basic and clinical antibacterial agents, antiviral, antiprotozoals, antituberculuous, antifungal and antihelminthes agents. All manuscripts must be prepared in English, and are subject to a rigorous and fair peer-review process. Accepted papers will immediately appear online. The journal aims to advance the knowledge, attitude and the research of chemotherapy in the Arabic world in cooperation with international, national scientific and public societies as well as research centers with similar aims and objectives. 